\title{
Screening of Antimicrobial Activity Compounds from Korea Ginseng Fine Root
}

\author{
Ah-Reum Kim and Myung-Suk Lee*
}

Department of Microbiology, Pukyong National University, Busan 608-737, Korea

Received May 25, 2011 /Revised September 5, 2011 /Accepted September 16, 2011

\begin{abstract}
The study was performed to evaluate the antibacterial and antiviral activities of ginseng fine root in order to search for antibacterial substances. Among 8 kinds of fermentation strains, Lactobacillus plantarum was selected based on viable cell count and antibacterial activities during incubation. Optimum conditions of ginseng fine root fermentation for $L$. plantarum were incubation at $35^{\circ} \mathrm{C}$ for $48 \mathrm{hr}$ in $5 \%$ ginseng fine root broth. That methanolic extract of fermented ginseng fine root broth was observed to be antibacterial and have antiviral activities. The results of paper disc method of non-fermented extract and fermented extract measured against $E$. coli was $11 \mathrm{~mm}$ and $20 \mathrm{~mm}, S$. aureus was $15 \mathrm{~mm}$ and $22 \mathrm{~mm}$, respectively. Shaking flask method was observed to inhibit the growth E. coli and S. aureus in fermented extract by $99.9 \%$. However, antiviral activity of Feline calicivirus (FCV) was mostly activated. Fermented extract was used to investigate the compositional changes of ginsenosides on HPLC analysis. By fermentation, ginsenoside Rg1, Re and Rd were increased, with $\mathrm{Rd}$ showing a significant increase of $50 \mathrm{\mu g} / \mathrm{g}$. These results suggest that ginseng fine root extract is a useful resource.
\end{abstract}

Key words : Ginseng fine root, Lactobacillus plantarum, antibacterial activity, antiviral activity, HPLC

\section{서 론}

인삼(Panax ginseng)은 C.A. Meyer가 1843년에 '만병을 치 료한다.'는 뜻으로 Panax ginseng C.A. Meyer로 명명 하였으며, 한국에서 생산되는 고려인삼(Korea ginseng)의 품질이 가장 좋 은 것으로 인지되어 동, 서양에서 약재로 널리 사용되고 있다. 고려인삼은 오가피나무과(Araliaceae) 인삼 속(Panax)에 속하 는 다년생 초본류로서 형태는 지상부인 꽃(열매), 잎, 줄기와 지하부인 뇌두, 주근(굵은 동체부위), 지근(동체의 아래쪽으로 뻗어 나온 굵은 다리), 세근(지근에서 발생 된 가는 뿌리)으로 이루어져 있으며[9], 동양권에서는 오래 전부터 지하부인 뿌리 부분을 약초로서 광범위하게 사용하여 왔다[19,20,26].

고려인삼의 주요 약리작용으로는 중추신경계의 흥분 진정 작용[2], 항암 작용[13], 혈압조절 작용[12], 항당뇨 작용[8], 항 산화 작용[10], 항균 작용[7]등에 효과가 있는 것으로 보고되고 있다. 이는 고려인삼의 주요 성분인 40 여 종 이상의 사포닌 (saponin)을 비롯하여 비사포닌(non-saponin) 계열인 polyacetylene, polysaccharides, alkaloids, phenolic compounds 등에 의한 약효로 알려져 있으며, 이들 유효성분들 중 가장 중요한 약리활성 성분인 사포닌은 triterpenoid계의 dammarane계를 기본 골격으로 하여, 다른 식물 사포닌과는 달리 과량 투여에 의한 독성이 없을 뿐 아니라 용혈작용이 거의 없는 중성 배당체로 보고되고 있다[3]. 약용 대상이 되는 지하부 즉

*Corresponding author

Tel : +82-51-629-5615, Fax : +82-51-629-5619

E-mail : leems@pknu.ac.kr
뿌리의 부위별 사포닌 함량을 비교한 연구에 의하면 총 사포 닌의 함량은 주근과 지근이 각각 $1.02 \%, 3.94 \%$ 이며, 세근은 $8.31 \%$ 가 함유 되어 있는 것으로 밝혀졌다[17]. 이처럼 세근에 는 약재로 이용되는 주근과 지근에 비해 2배 이상 많은 사포닌 을 함유하고 있으나 사포닌의 질적 비율이 양적 비율보다 중 시되고 있어 세근의 약재 및 상품적 가치가 인정 받지 못하고 있으며, 세근의 일부만이 캔디, 젤리, 비누[4] 등에 이용되고 대부분 폐기되는 실정이다. 또한, 세근의 상품적 가치 증대를 위한 유효성 및 기능성에 대한 체계적인 연구도 미미한 실정 이다.

따라서 본 연구는 세근에 함유된 사포닌 성분의 항균성 및 항바이러스 분석과 발효에 적합한 유용 미생물을 선별하여 이를 발효시킨 결과 항균성 및 항바이러스 작용에 영향을 주 는 인자의 성분 변화를 확인하였기에 이를 보고자 하며, 이 결과를 통해 세근의 약재 및 상품적 가치의 증대를 위한 기초 연구 데이터를 제공하고자 한다.

\section{재료 및 방법}

\section{실험 재료}

본 실험에 사용된 인삼은 국내산 고려인삼으로 충남 금산 지역에서 재배된 4 년생 인삼을 구입하여, 실험실에서 2차 증 류수로 2 3회 세척 후 자연 건조하였다. 건조된 인삼은 세근만 을 분리하여 분쇄기로 마쇄하여 분말로 만들어 $-20^{\circ} \mathrm{C}$ 에 보관 하며 실험에 사용하였다. 


\section{사용 균주 및 전 배양}

인삼 세근 발효를 위해 인삼의 배당체 분해에 적절한 세균 6 종, 곰팡이 1종, 효모 1종[5,15]을 사용하였으며 이를 Table 1 에 나타내었다. 본 실험에 사용된 곰팡이와 효모는 Potato dextrose broth (Difco, U.S.A.)와 Yeast Mold broth (Difco, U.S.A.)를 사용하여 $25^{\circ} \mathrm{C}, 150 \mathrm{rpm}, 48$ 시간 동안 교반 배양 하였다. 유산균은 MRS broth (Difco, U.S.A.), 그 외 모든 세균 은 Nutrient broth (Difco, U.S.A.)를 이용하여 $35^{\circ} \mathrm{C}, 150 \mathrm{rpm}$, 24 시간 동안 교반 배양 하였다.

\section{일반성분 분석}

일반성분 분석을 위해 식품공전[18]에 나와 있는 방법을 사 용하여, 수분은 $105^{\circ} \mathrm{C}$ 상압가열건조법, 조단백질은 semi-micro Kjeldahl법, 조지방 함량은 Soxhlet법, 조회분은 $550{ }^{\circ} \mathrm{C}$ 직 접 회화법으로 측정하였다. 탄수화물은 총 100 에서 수분, 조단 백질, 조지방 및 조회분을 뺀 값으로 계산하여 구하였다.

\section{인삼 세근 발효를 위한 균주 선별 및 배지 제조}

인삼 세근의 발효에 적합한 균주를 선별하기 위해 세근 분 말 배지(DW $100 \mathrm{ml}$, 세근 분말 $5 \%$ )를 제조하여 Table 1에 표시된 각각의 발효 균주를 $1 \%(6.0 \log \mathrm{CFU} / \mathrm{ml})$ 접종하고 전 배양과 동일한 조건으로 72 시간 배양하며 생균수 및 배양 액의 항균성(paper disc)을 비교 분석하였다. 또한, 선정된 균 주의 최적 발효를 위하여 세근 분말을 배지에 각각 2.5 30\% $(\mathrm{w} / \mathrm{v})$ 로 첨가하여 균주 선정과 동일한 방법으로 배양하며 생 균수 및 배양액의 항균성(paper disc)을 평가하였다.

\section{항균성 물질 추출법}

발효 된 세근 분말 배지를methanol과 1:10 비율로 혼합하고 $70^{\circ} \mathrm{C}$ 에서 3 시간 동안 3 회 교반 추출하여 이를 여과한 뒤 $45^{\circ} \mathrm{C}$ 항온수조에서 rotary evaporator로 감압 농축하였다. 이를 dimethyl sulfoxide (DMSO; Kanto, Japan)에 녹인 후 $-20^{\circ} \mathrm{C}$ 에 보관하여 항균성 및 항바이러스 활성 실험에 사용하였다.

\section{추출물의 항균성 측정}

추출물의 항균성 분석은 paper disc법[16]과 shaking flask
법[21]을 이용하여 Escherichia coli와 Staphylococcus aureus를 대 상으로 측정하였다. Paper disc법은 disc $(8 \mathrm{~mm}$; Tokyo, Japan)에 추출물을 $5 \mathrm{mg} / \mathrm{disc}$ 로 흡수시켜 $35^{\circ} \mathrm{C}, 24$ 시간 배양 후 clear zone의 직경을 측정하여 항균성을 평가하였다. Shaking flask법은 중화용액 $(0.2 \%$ Nutrient broth)에 각각 5 $\mathrm{mg} / \mathrm{ml}$ 의 추출물과 초기 균수 $5.0 \log \mathrm{CFU} / \mathrm{ml}$ 정도의 시험균 (E. coli, S. aureus)을 접종하여 $35^{\circ} \mathrm{C}, 150 \mathrm{rpm}$ 으로 12 시간 단위 로 두번 반응 시킨 후 pour-plate 법으로 균의 감소율을 확인하 였다. 감소율은 아래의 식으로 계산하여 항균활성을 측정하였 다. 이때 추출액을 첨가하지 않고 동일 조건에서 일정시간 배 양된 시험 균액을 대조구(control)로 비교 분석하였다. 모든 실험은 3 회 이상 실시하여 이의 평균값을 도출하였다.

Bacterial reduction rate $(\%)=\{1-(\mathrm{Me} / \mathrm{Mc})\} \times 100$

Me: Microorganism number of experiment

Mc: Microorganism number of control.

\section{추출물의 항바이러스 활성}

추출물의 항바이러스 활성 분석을 위하여 $50 \%$ tissue culture infectious dose $\left(\mathrm{TCID}_{50}\right)$ 방법으로 Feline calicivirus $(\mathrm{FCV})$ 의 감염가를 측정하였다[6]. 숙주세포인 Crandall-reese Feline kidney cell (CrFK cell, ATCC CCL-94)은 2\% Fetal bovine serum (FBS), $100 \mathrm{U} / \mathrm{ml}$ Penicillin 과 $100 \mathrm{\mu g} / \mathrm{ml}$ Streptomycin 이 포함된 Dulbecco modified eagle medium (DMEM)을 이용 하여 96 well plate에 $37^{\circ} \mathrm{C}, 5 \% \mathrm{CO}_{2}$, 48 시간 배양하여 monolayer를 얻었다. $5.0 \mathrm{TCID}_{50} / \mathrm{ml}$ 로 희석된 $\mathrm{FCV}$ 와 추출물을 $1: 1$ 로 혼합하고 실온에서 $1,6,12,24$ 시간별로 반응하여 $50 \mu \mathrm{l}$ 씩 4개의 well에 접종하고 90 분간 방치하여 $\mathrm{FCV}$ 를 $\mathrm{CrFK}$ cell에 감염시켰다. 그 후 growth medium을 aspirate로 제거하고 $100 \mu 1$ 의 maintenance medium (DMEM $+2 \% \mathrm{FBS}$ )을 다시 첨가하여 $37^{\circ} \mathrm{C}, 5 \% \mathrm{CO}_{2}$ 조건으로 3 4일 배양하며 세포병변효 과(cytopathic effects)를 현미경으로 관찰하였다. 배양이 완료 되면 3.4\% formaldehyde 용액으로 cell을 고정하고 $0.1 \%$ crystal violet으로 가시화하였다. 이때 대조구로는 추출물 대신 maintenance medium을 희석된 FCV와 혼합한 것으로 비교 분석 하였고, 바이러스 감염가는 Reed-Muench method로 $50 \%$ 이상 $\mathrm{CPE}$ 가 나타난 well의 희석단계를 산정하여 $\log$

Table 1. Various microorganisms used for this study

\begin{tabular}{lll}
\hline Strains for fermentation & Antibacterial activity & Antiviral activity \\
\hline Lactobacillus plantarum (KCTC 3103) & & \\
Lactobacillus brevis (KCTC 3498) & & \\
Lactobacillus rhamnosus (KCTC 3237) & Escherichia coli (KCTC 12006) & Feline calicivirus (ATCC VR-782) \\
Enterococcus feacium (KCCM 12118) & Staphylococcus aureus (KCTC 1621) & \\
Aspergillus oryzae (KCTC 6291) & \\
Candida utilis (ATCC 16321) & & \\
Bacillus subtilis (KCTC 1024) & \\
Bacillus megaterium (KCTC 1098) & & \\
\hline
\end{tabular}


$\mathrm{TCID}_{50} / \mathrm{ml}$ 로 표기하였다[11].

\section{추출물의 HPLC 분석}

인삼 세근 추출물의 분석을 위해 HPLC (High Performance Liquid Chromatography) 분석법을 사용하였다. HPLC장비는 Agilent 1100 (Agilent Tech, U.S.A.)를 이용하였으며, Column 은 Shiseido $C_{18}(5 \mu \mathrm{m}, 4.6 \mathrm{~mm} \times 250 \mathrm{~mm}$, Japan)를 사용하였 고, column 온도는 $35^{\circ} \mathrm{C}$ 이다. 각각의 시료는 $10 \mu 1$ 를 주입하였 고, 이동상으로는 acetonitrile과 water를 사용하여 Table 2와 같은 gradient 조건에 의해 $1 \mathrm{ml} / \mathrm{min}$ 의 유속으로 총 65 분간 분리하였다. 분리된 추출물은 UV detector로 $203 \mathrm{~nm}$ 에서 측 정하여 표준물질과 비교 분석하였으며 표준물질인 ginsenoside Rg1, Re, Rb1, Rc, Rb2, Rd는 Extrasynthese S.A (France) 에서 구입하였다.

\section{결과 및 고찰}

\section{일반성분 분석}

본 연구에 사용된 충남 금산 지역 4 년근 인삼 세근의 성분 분석 결과는 수분 $10.8 \%$, 조회분 $5.7 \%$, 조지방 $1.2 \%$, 조단백질 $15.8 \%$ 와 탄수화물 $66.5 \%$ 가 함유된 것으로 분석 되었으며, 이 를 Table 3에 정리하였다. 본 연구 결과와 Lee [24]가 보고한 강화도 지역 6 년생 인삼 근의 성분 결과 비교 시 조회분을 제외한 다수의 다른 성분들과는 함량 차이가 없었다. 이와 같 은 결과는 인삼의 영양성분이 재배지 및 재배 년수 등에 따른 차이는 있으나 구성 성분의 함량 비율 차이는 없는 것으로 확인된다. 또한, 인삼의 일반성분 분석 결과 대부분이 탄수화 물로 구성 됨을 확인할 수 있었다. 이는 인삼의 주요 기능(항산 화 활성, 항균성 등)을 나타내는 성분이 사포닌 또는 진세노사 이드(ginsenosides)라는 물질로 알려져 있으며, 이들은 복합 탄수화물이기 때문에 인삼 전체 구성 성분 중 탄수화물 함량 비율이 가장 높은 것으로 추정된다.

\section{인삼 세근 발효에 적합한 균주 및 배지 농도 선정}

인삼 세근 발효를 위한 균주를 선별하기 위해 균 성장에 따른 항균력을 분석하여 발효에 적합한 균주를 선별 하였다. 이를 위하여 인삼 세근을 유일한 영양원으로 하는 $5 \%$ 세근 분말 배지를 제조한 다음 Table 1에 제시된 균주를 72 시간 동

Table 2. Solvent gradient program of HPLC analysis

\begin{tabular}{ccc}
\hline Time & Water $(\%)$ & Acetonitrile $(\%)$ \\
\hline 0 & 80 & 20 \\
17 & 80 & 20 \\
27 & 70 & 30 \\
44 & 65 & 35 \\
54 & 70 & 30 \\
65 & 80 & 20 \\
\hline
\end{tabular}

Table 3. Proximate compositions of ginseng fine root

(dry base, \%)

\begin{tabular}{lr}
\hline Components & Fine root \\
\hline Moisture & $10.8 \pm 0.3$ \\
Crude ash & $5.7 \pm 0.3$ \\
Crude lipid & $1.2 \pm 0.1$ \\
Crude protein & $15.8 \pm 0.7$ \\
Carbohydrate & $66.5 \pm 0.5$ \\
\hline
\end{tabular}

Values are mean \pm SD of triplicate determinations.

안 배양하여 생장능과 배양액의 항균성을 분석하였으며 그 결과를 Table 4에 나타내었다. 표에서 보는 바와 같이 최대 생장률은 48 시간 이였으며, 동일 배양 시간에서 세균과 진균 류의 생장능 및 항균력은 세균이 우세한 것으로 나타났고, 유 산균과 Bacillus 속을 비교 시 유산균의 생장능 및 항균력이 뛰어난 것으로 확인되었다. 이는 $\mathrm{Kim}$ 등[14]이 유산균과 Bacillus속의 인삼 발효능을 비교한 연구에서 유산균이 Bacillus 속에 비해 단시간에 우수한 증식을 나타낸다는 보고와 일치하 는 결과를 보여주고 있다. 또한, 유산균 중 생장능 및 항균력이 가장 뛰어난 종은 Lactobacillus plantarum으로 초기 접종 균수 대비 1,000 배 이상의 생장능과 약 2 배 정도 높은 항균력을 나 타내고 있으며, 이는 Park 등[25]의 인삼 배지에서 증식 가능한 유산균주의 선별 중 $L$ plantarum이 초기 접종 균수 대비 800 배 이상의 우수한 증식률을 나타낸 보고와도 일치한다. 이와 같 은 결과로 인삼 세근 발효를 위한 최적 균주로 L. plantarum을 선정 하였다. 또한, L. plantarum의 발효능 증대를 위한 세근 분말 배지 조성을 선정하기 위해 세근 분말농도를 각각 $2.5 \sim 30 \%(\mathrm{w} / \mathrm{v}$ )로 첨가하여 균주 선정과 동일한 조건으로 72 시간 배양하며 생장능과 항균력을 분석하였으며 이 결과를 Table 5에 요약 정리 하였다. 각각의 세근 분말 농도에서 $L$. plantarum은 48 시간대에 최대 증식률을 보였으며, $5 \%$ 와 $10 \%$ 에서 최대 항균 활성을 나타내었다.

이와 같은 결과를 토대로 인삼 세근 발효에 적합한 조건으 로 최적 균주는 L. plantarum이며 세근 분말 배지의 분말 농도 는 $5 \%$ 인 것으로 분석되어 이후의 실험은 선정된 조건으로 진 행하였다.

\section{인삼 세근 발효 추출물의 항균 및 항바이러스 분석}

인삼 세근 발효 추출물의 항균 활성 분석을 위해 paper disc 법과 shaking flask법을 이용하였다. Paper disc법에 의한 항균 활성은 $5 \mathrm{mg} / \mathrm{disc}$ 의 세근 분말 배지를 이용한 비발효 추출물 과 발효 추출물을 비교 분석 하였다. Fig. $1 \mathrm{~A}$ 는 E. coli에 대한 생육 저해환으로 직경이 각각 $11 \mathrm{~mm} \mathrm{(1;} \mathrm{비발효)와} 20 \mathrm{~mm}$ (2; 발효)로 나타났으며, Fig. $1 \mathrm{~B}$ 는 $S$. aureus에 대한 결과로 생 육 저해환의 직경이 각각 $15 \mathrm{~mm}$ (1; 비발효)와 $22 \mathrm{~mm} \mathrm{(2;}$ 발효)로 나타났다. 또한, shaking flask법에 대한 결과는 24시 간 반응 후 발효 추출액 $5 \mathrm{mg} / \mathrm{ml}$ 에서 E. coli 와 S. aureus의 
Table 4. Change of viable cells count and antibacterial activity in ginseng fine root broth incubated by various microorganisms during incubation

\begin{tabular}{|c|c|c|c|c|}
\hline \multirow{2}{*}{ Microorganism } & \multicolumn{4}{|c|}{ Incubation time $(\mathrm{hr})$} \\
\hline & 0 & 24 & 48 & 72 \\
\hline \multirow{2}{*}{ Lactobacillus plantarum } & $6.36 \pm 0.4^{1)}$ & $8.64 \pm 0.3$ & $9.85 \pm 0.4$ & $9.67 \pm 0.4$ \\
\hline & $8^{2)}$ & 13 & 15 & 14.5 \\
\hline \multirow{2}{*}{ Lactobacillus brevis } & $6.52 \pm 0.3$ & $6.99 \pm 0.2$ & $6.69 \pm 0.4$ & $6.63 \pm 0.3$ \\
\hline & 8 & 10 & 12 & 12 \\
\hline \multirow{2}{*}{ Lactobacillus rhamnosus } & $6.68 \pm 0.4$ & $7.98 \pm 0.1$ & $8.28 \pm 0.3$ & $7.96 \pm 0.2$ \\
\hline & 8 & 12 & 12.5 & 12 \\
\hline \multirow{2}{*}{ Enterococcus feacium } & $6.70 \pm 0.4$ & $6.88 \pm 0.1$ & $6.53 \pm 0.5$ & $6.34 \pm 0.2$ \\
\hline & 8 & 11.5 & 12 & 11 \\
\hline \multirow{2}{*}{ Aspergillus oryzae } & $6.15 \pm 0.3$ & $6.93 \pm 0.3$ & $6.80 \pm 0.1$ & $6.72 \pm 0.2$ \\
\hline & 8 & 8 & 8 & 8 \\
\hline \multirow{2}{*}{ Candida utilis } & $6.81 \pm 0.2$ & $7.76 \pm 0.3$ & $8.04 \pm 0.2$ & $8.00 \pm 0.4$ \\
\hline & 8 & 8 & 8 & 8 \\
\hline \multirow{2}{*}{ Bacillus subtilis } & $6.97 \pm 0.2$ & $7.70 \pm 0.3$ & $8.96 \pm 0.1$ & $8.81 \pm 0.2$ \\
\hline & 8 & 8 & 8 & 8 \\
\hline \multirow{2}{*}{ Bacillus megaterium } & $6.94 \pm 0.1$ & $8.28 \pm 0.4$ & $7.08 \pm 0.5$ & $7.04 \pm 0.4$ \\
\hline & 8 & 8 & 8 & 8 \\
\hline
\end{tabular}

${ }^{1)}$ Viable cell count is average of triplicate determinations $(\log \mathrm{CFU} / \mathrm{ml})$.

${ }^{2)}$ Antibacterial activity of Escherichia coli $(\mathrm{mm})$. Paper disc dimeter $(8 \mathrm{~mm})$ was included.

Table 5. Change of viable cell counts and antibacterial activity in ginseng fine root broth incubated by various concentration during incubation

\begin{tabular}{|c|c|c|c|c|}
\hline \multirow{2}{*}{ Concentration (\%) } & \multicolumn{4}{|c|}{ Incubation time $(\mathrm{hr})$} \\
\hline & 0 & 24 & 48 & 72 \\
\hline \multirow[b]{2}{*}{2.5} & $6.57 \pm 0.4^{1)}$ & $7.73 \pm 0.3$ & $7.26 \pm 0.5$ & $7.23 \pm 0.4$ \\
\hline & $8^{2)}$ & 11.5 & 12.5 & 12.5 \\
\hline \multirow{2}{*}{5} & $6.65 \pm 0.3$ & $8.59 \pm 0.4$ & $9.72 \pm 0.2$ & $9.66 \pm 0.3$ \\
\hline & 8 & 13 & 15 & 15 \\
\hline \multirow{2}{*}{10} & $6.32 \pm 0.1$ & $8.88 \pm 0.3$ & $9.32 \pm 0.4$ & $9.15 \pm 0.3$ \\
\hline & 8 & 12 & 15 & 14.5 \\
\hline \multirow{2}{*}{20} & $6.56 \pm 0.5$ & $7.71 \pm 0.3$ & $8.18 \pm 0.3$ & $7.99 \pm 0.2$ \\
\hline & 8 & 13 & 14 & 13.5 \\
\hline \multirow{2}{*}{30} & $6.79 \pm 0.2$ & $7.87 \pm 0.3$ & $8.15 \pm 0.2$ & $8.00 \pm 0.2$ \\
\hline & 8 & 12.5 & 14 & 13.5 \\
\hline
\end{tabular}

1), ${ }^{2)}$ The same as Table 1.

성장을 $99.9 \%$ 억제시키는 것으로 분석 되었으며, 이를 Table 6 에 정리하였다. 이상의 두 실험에 대한 결과를 분석하면 인삼 세근 발효 추출물이 비발효 추출물 보다 항균 활성력이 뛰어 난 것으로 분석되며, Gram negative균과 Gram positive균에 대한 항균 활성은 큰 차이를 보이진 않지만 Gram positive균 에 대한 활성이 좀 더 뛰어나다고 사료된다.

항바이러스 활성 분석은 최근 식중독 바이러스로 문제가 되고 있는 노로바이러스를 대체한 모델인 $\mathrm{FCV}$ 의 감염가로 분석하였으며 재료 및 방법에 서술 된 방법으로 측정하였다. 항바이러스 활성 효과는 $\log \mathrm{TCID}_{50} / \mathrm{ml}$ 값이 $4 \log$ 이상 감소 하였을 때 virucidal activity가 인정된다[1]. 하지만 인삼 세근 의 발효 및 비발효 추출물에서는 Table 7에서 보는 바와 같이
$\mathrm{TCID}_{50} / \mathrm{ml}$ 값이 최대 약 $1 \log$ 감소되었기 때문에 항바이러스 활성은 없는 것으로 판단된다.

\section{인삼 세근 발효 추출물의 HPLC 분석}

인삼 세근 발효 추출물의 항균 및 항바이러스 분석 결과 항균성만 있는 것으로 분석되어 추출물의 성분 분석을 위해 HPLC 분석을 실시하였다. Kwak 등[22]은 홍삼 사포닌이 병 원성 미생물인 $S$. aureus의 성장에 미치는 영향을 조사한 결과 사포닌에 농도 의존적으로 균의 성장이 크게 억제되는 것을 보고하였고, Jun 등[7]은 세균의 생육에 미치는 인삼 성분을 조사한 결과 ginsenoside Rg1과 Rd가 항균효과를 나타내는 것으로 보고 하였다. 이에 본 연구에서 나타난 인삼 세근 발효 
A)

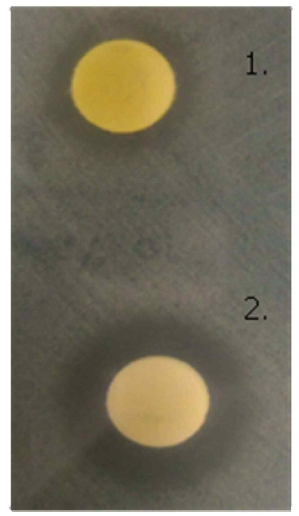

B)

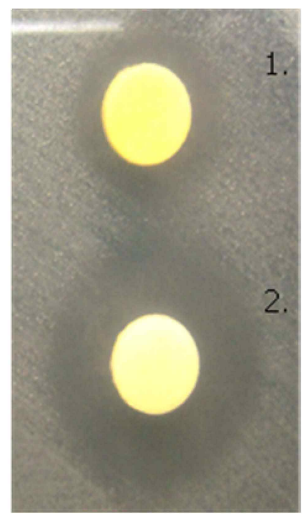

Fig. 1. Effect of $L$ plantarum fermentation on paper disc method of ginseng fine root methanol extract. (A) Antibacterial activity of Escherichia coli; (B) Antibacterial activity of Staphylococcus aureus.1, non fermentation; 2, fermented ginseng fine root by $L$ plantarum
추출물의 항균 활성은 세근에 다량 함유된 ginsenoside에 영 향인 것으로 추정되어, 인삼 세근 발효 추출물과 6 종의 ginsenoside 표준물질을 HPLC로 비교 분석하여 Fig. 2에 나타 내었다. Fig. $2 \mathrm{~A}$ 는 6 종의 ginsenoside 표준물질을 분석한 결과 이며, Fig. $2 B, C$ 는 비발효 추출물 및 발효 추출물을 분석한 결과로 동일 시간대에서 표준물질과 같은 peak가 나타나기 때문에 비발효 및 발효 추출물의 주된 성분은 표준물질과 동 일한 물질이라 추정된다. 또한, 인삼 세근 분말 배지의 발효 시 성분 변화는 protopanaxadiol $(\mathrm{PD})$ 계열의 $\mathrm{Rd}$ 와 protopanaxtriol (PT) 계열의 Rg1, Re가 선택적으로 증가하였 고 그 외 $\mathrm{PD}$ 계열의 $\mathrm{Rb} 1, \mathrm{Rc}, \mathrm{Rb} 2$ 는 감소되어 6가지 성분들 간의 변화를 확인 할 수 있었다. Kim 등[14]에 따르면 인삼분말을 Bacillus spp.로 발효시킨 결과 Rc, Rb1 및 Rb2가 ginsenoside-a -arabinofuranase에 의해 $\mathrm{Rd}$ 로 전환되는 것을 보고하였는데, 본 연구 또한 $\mathrm{PD}$ 계열의 $\mathrm{Rb} 1, \mathrm{Rc}, \mathrm{Rb} 2$ 가 감소되고 $\mathrm{Rd}$ 가 증가되

Table 6. Antibacterial effect of L. plantarum fermentation on shaking flask method of ginseng fine root methanol extract

$(\mathrm{CFU} / \mathrm{ml})^{1)}$

\begin{tabular}{|c|c|c|c|c|c|c|}
\hline \multirow{2}{*}{ Sample } & \multicolumn{3}{|c|}{ E. coli } & \multicolumn{3}{|c|}{ S. aureus } \\
\hline & $0 \mathrm{hr}$ & $12 \mathrm{hr}$ & $24 \mathrm{hr}$ & $0 \mathrm{hr}$ & $12 \mathrm{hr}$ & $24 \mathrm{hr}$ \\
\hline Control $^{2)}$ & $4.7 \times 10^{5}$ & $2.2 \times 10^{8}$ & $4.2 \times 10^{8}$ & $1.2 \times 10^{5}$ & $6.2 \times 10^{7}$ & $5.4 \times 10^{8}$ \\
\hline \multirow{2}{*}{$\mathrm{NFG}^{3)}$} & $4.7 \times 10^{5}$ & $1.8 \times 10^{8}$ & $1.1 \times 10^{8}$ & $1.2 \times 10^{5}$ & $6.8 \times 10^{6}$ & $9.9 \times 10^{5}$ \\
\hline & - & $18.18 \%^{5)}$ & $73.81 \%$ & - & $89.03 \%$ & $99.82 \%$ \\
\hline \multirow{2}{*}{$\mathrm{FG}^{4)}$} & $4.7 \times 10^{5}$ & $5.0 \times 10^{2}$ & $1.9 \times 10^{1}$ & $1.2 \times 10^{5}$ & $9.5 \times 10^{3}$ & $1.7 \times 10^{1}$ \\
\hline & - & $99.99 \%$ & $99.99 \%$ & - & $99.98 \%$ & $99.99 \%$ \\
\hline
\end{tabular}

${ }^{1)}$ Average of triplicate determinations, ${ }^{2)}$ Ginseng fine root extract was not added.

${ }^{3)}$ Non Fermented Ginseng, ${ }^{4)}$ Fermented Ginseng (Fermented for 48 hr by L. plantarum).

${ }^{5}$ Bacterial reduction rate $(\%)=\{1-(\mathrm{Me} / \mathrm{Mc})\} \times 100$

Me: Microorganism number of experiment, Mc: Microorganism number of control.

Table 7. Virucidal activity of ginseng fine root extract against Feline calicivirus

$\left(\mathrm{TCID}_{50} / \mathrm{ml}\right)^{1)}$

\begin{tabular}{ccccccc}
\hline \multirow{2}{*}{ Ginseng } & $\begin{array}{c}\text { Concentration } \\
(\mathrm{mg} / \mathrm{ml})\end{array}$ & $0 \mathrm{hr}$ & $1 \mathrm{hr}$ & $6 \mathrm{hr}$ & $12 \mathrm{hr}$ & $24 \mathrm{hr}$ \\
\cline { 3 - 7 } & 20 & & 5.6 & 5.6 & 5.1 & 4.1 \\
& 10 & & 5.6 & 5.6 & 5.2 & 4.1 \\
\multirow{3}{*}{$\mathrm{NFG}^{2)}$} & 5 & 5.6 & 5.6 & 5.6 & 5.2 & 4.6 \\
& 2.5 & & 5.6 & 5.6 & 5.2 & 5.1 \\
& 1.25 & & 5.6 & 5.6 & 5.2 & 5.2 \\
$\ldots \ldots \ldots \ldots$ \\
\end{tabular}

${ }^{1)}$ Average of triplicate determinations.

${ }^{2)}$ Non Fermented Ginseng, ${ }^{3)}$ Fermented Ginseng (Fermented for $48 \mathrm{hr}$ by L. plantarum).

${ }^{4)}$ Ginseng fine root extract was not added. 

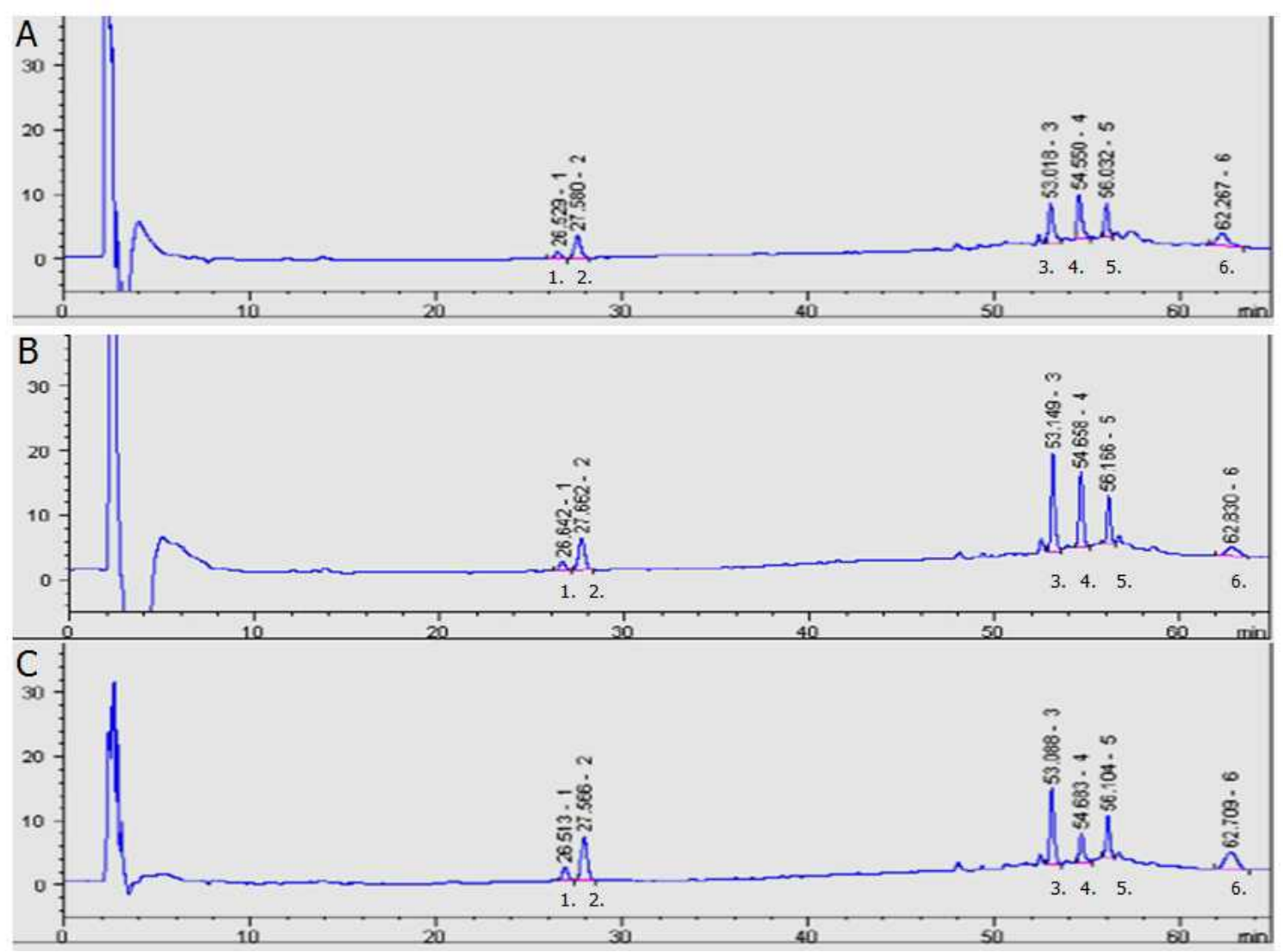

Fig. 2. HPLC profiles of transfomiation of ginsenoside Rg1, Re, Rb1, Rc, Rb2 and Rd by L plantarum (A) standard; (B) non fermentation; (C) fermented ginseng fine root by L. plantarum Ginsenosides; 1, Rg1; 2, Re; 3, Rb1; 4, Rc; 5, Rb2; 6, Rd.

Table 8. Changes of ginsenosides composition in ginseng fine root by L. plantarum

\begin{tabular}{|c|c|c|c|c|c|c|}
\hline \multirow{2}{*}{ Sample } & \multicolumn{6}{|c|}{ Content $(\mu \mathrm{g} / \mathrm{g})$} \\
\hline & Rg1 & $\operatorname{Re}$ & $\mathrm{Rb} 1$ & Rc & $\mathrm{Rb} 2$ & $\mathrm{Rd}$ \\
\hline $\mathrm{NFG}^{1)}$ & 74.14 & 136.85 & 627.50 & 413.91 & 252.90 & 261.91 \\
\hline $\mathrm{FG}^{2)}$ & 86.01 & 148.81 & 514.82 & 188.33 & 213.24 & 311.84 \\
\hline
\end{tabular}

${ }^{1)}$ Non Fermented Ginseng, ${ }^{2)}$ Fermented Ginseng (Fermented for $48 \mathrm{hr}$ by L. plantarum).

어 ginsenoside-a-arabinofuranase효소의 영향인 것으로 사료 된다. 인삼 세근 발효 추출물의 ginsenoside 정량 분석 결과는 Table 8 에 정리하였으며, 이 중 가장 많은 함량 변화를 보인 성분은 $\mathrm{Rd}$ 로 약 $50 \mu \mathrm{g} / \mathrm{g}$ 이 증가되었다. 본 연구에서 확인된 세근 발효 추출액의 항균활성은 ginsenoside $\mathrm{Rd}$ 성분에 의한 것으로 추정되며, 세근으로 발효된 추출액이 정제된 물질이 아닌 점을 고려한다면, ginsenoside $\mathrm{Rd}$ 에 상당한 항균기능이 있는 것으로 판단된다.

따라서 인삼의 주근과 지근 못지 않게 다량의 사포닌이 함 유된 세근을 부산물로 취급하여 폐기 하기 보다는 본 연구를 통해 얻어진 결과를 토대로 인삼 세근 분말 농도 $5 \%$ 와 Lactobacillus plantarum으로 발효하여 항균성이 뛰어난 ginsenoside $\mathrm{Rd}$ 를 생산한다면 인삼 세근의 새로운 이용 방법을 제
시 할 수 있을 것으로 사료된다.

\section{References}

1. Bellamy, K. 1995. A review of the test methods used to establish virucidal activity. J. Hosp. Infect. 30, 389-396.

2. Benishin, G. C. 1992. Actions of ginsenoside Rb1 on choline uptake in central cholinegic nerve endings. Neurochem Int. 21, 1-5.

3. Chang, H. K. 2003. Effect of processiong methods on the saponin contents of Panax ginseng leaf-tea. Korean J. Food Nutr. 16, 46-53.

4. Choi, J. E., Y. H. Han, and K. T. Lee. 2009. Changes of saponin contents of leaves, stems and flower-buds of Panax ginseng C.A. meyer by harvesting days. Korean J. Crop Sci. 17, 
251-256

5. Doosan. Co., Ltd. 2008. Fermented ginseng containing bio-conversed ginsenoside metabolites increased by co-fermentation of fungi and lactic acid bacteria. KR-A 10-2008-0103299.

6. Gehrke, C., J. Steinmann, and P. Goroncy-Bermes. 2004. Inactivation of feline calicivirus, a surrogate of norovirus(formerly Norwalk-like viruses), by different types of alcohol in vitro and in vivo. J. Hosp. Infect. 56, 49-55.

7. Jun, H. K., S. H. Kim, and K. L. Jong. 1982. Studies of ginseng the components on the growth of bacteria. Korean J. Appl. Microbiol. Bioeng. 10, 101-108.

8. Huo, Y. and Y. Chen. 1998. The effect of Panax ginseng extract on insulin and corticosteroid receptors. J. Traditional Chinese Medicine 8, 293-295.

9. Jo, J. S., S. G. Mok, and J. Y. Weon. 1998. Culture of latest ginseng. pp. 34, Seonjinmunawsa, Seoul.

10. Jung, N. P. and S. H. Jin. 1996. Studies on the physiological and biochemical effects of Korea ginseng. Korean J. Ginseng Sic. 20, 431-471.

11. Kampf, G., D. Grotheer, and J. Steinmnn. 2005. Efficacy of three ethanolbased hand rubs against feline calicivirus, a surrogate virus for norovirus. J. Hosp. Infect. 60, 144-149.

12. Kang, S. Y. and N. D. Kim. 1992. The antihypertensive effect of red ginseng saponin and the endothelium-derived vascular relaxation. Korean J. Ginseng Sic. 18, 175-182.

13. Kikuchi, Y., H. Sasa, T. Kita, J. Hirata, and T. Tode. 1991. Inhibition of human ovarian cancer cell proliferation in vitro by ginenoside- $\mathrm{Rb} 2$ and adjuvant effects of cisplatin in vivo. Anticancer Drugs (England) 2, 63-67.

14. Kim, H. G., K. Y. Kim, and C. J. Cha. 2007. Screening for ginseng-fermenting microorganisms capable of biotransforming ginsenosides. Korean J. Microbiol. 43, 142-146.

15. Kim, J. B. and H. Hasegawa. 2003. Red ginseng containing deglycosylated ginsenosides and its manufacturing method. KR-A 2003-0041323.
16. Kim, M. J., M. W. Byun, and M. S. Jang. 1996. Physiological and antibacterial activity of bamboo (Sasa coreana Nakai) leaves. J. Korean Soc. Food Sci. Nutr. 25, 135-142.

17. Kim, M. W., S. R. Ko, K. J. Choi, and S. C. Kim. 1987. Distribution of saponin in various sections of Panax ginseng root and changes of its contents according to root age. J. Ginseng Res. 11, 10-16.

18. Korea Food and Drug Administration. 2010. Food code. pp. 212-251, Munyoungsa, Seoul.

19. Korea Ginseng and Tobacco Research Institute. 1994. Korea ginseng; chap. 5. process of ginseng. pp. 43-62, Korea Ginseng and Tobacco Research Institute.

20. Korean Ginseng History. 2002. Korea ginseng, pp.16-24, Donglimunhawsa, Seoul.

21. Korean Industrial Standard. 2001. Testing methods for antibacterial activity of antibacterial functional products-Part 1: Shaking flask method, KS M 0146.

22. Kwak, Y. K., M. H. Hwang, S. C. Kim, J. H. Do, and C. K. Park. 2006. A growth inhibition effect of saponin from red ginseng on some pathogenic microorganisms. J. Ginseng Res. 30, 128-131.

23. Lee, K. S., B. J. Seong, G. H. Kim, S. I. Kim, S. H. Han, H. H. Kim, and N. D. Baik. 2010. Ginsenoside, phenolic acid composition and physiological significances of fermented ginseng leaf. J. Korean Soc. Food Sci. Nutr. 39, 1194-1200.

24. Lee, S. D. 1985. A study on the change of cholesterol contents by supplement or the panax ginseng by products in the dietary protein level in rat's heart and testis. Korean J. Chemistry 2, 55-61.

25. Park, S. J., D. H. Kim, and N. S. Peak. 2006. Preparation and quality characteristics of the fermentation product of ginseng by lactic acid bacteria (FGL). J. Ginseng Res. 30, 88-94.

26. The Society for Korean Ginseng. 1995. Understanding of Korean Ginseng. pp 35-54, The Society for Korean Ginseng, Seoul.

\section{초록 : 고려인삼의 세근을 이용한 항균성 물질 탐색 \\ 김아름 · 이명숙* \\ (부경대학교 미생물학과)}

인삼의 효과적 이용을 위해 부산물로 취급되어 대부분 폐기되는 세근을 발효공학적 기법으로 항균성 물질을 증대하기 위한 연구이다. 이를 위해서 발효에 적합한 균주의 선별과 발효에 사용될 인삼 세근 분말의 농도를 선별하 여 발효 시킨 후 항균성 물질을 탐색하였다. 그 결과 8종의 유용 미생물 중 L. plantarum이 가장 적절한 균주로 선정 되었으며, 영양원인 인삼 세근 분말의 농도는 $5 \%$ 로 밝혀졌다. 또한, 발효 추출물의 항균 및 항바이러스 활성 분석 결과 항균성은 있으나 항바이러스 활성은 미약한 것으로 밝혀졌다. 항균 활성의 경우 비발효 추출물 보다 발효 추출물이 약 2 배 정도 증가되었고, Gram Positive 균주에서 활성이 더 좋은 것으로 분석 되었다. 발효에 의한 항균 활성 물질의 성분 변화를 알아 보기 위해서 HPLC 분석법을 사용하였으며 그 결과 ginsenoside Rg1, $\mathrm{Re}, \mathrm{Rd}$ 성분의 함량이 증가되었고, 이 중 가장 많은 함량 변화를 보인 성분은 $\mathrm{Rd}$ 로 약 $50 \mu \mathrm{g} / \mathrm{g}$ 이 증가되었다. 이러한 결과로부터 인삼 세근 발효물 중 항균 활성을 보이는 주된 물질은 ginsenoside Rd 성분인 것으로 추정된다. 